Atmos. Chem. Phys., 14, 2219-2231, 2014

www.atmos-chem-phys.net/14/2219/2014/

doi:10.5194/acp-14-2219-2014

(c) Author(s) 2014. CC Attribution 3.0 License.

\title{
Atmospheric mercury speciation and mercury in snow over time at Alert, Canada
}

\author{
A. Steffen ${ }^{1,2}$, J. Bottenheim ${ }^{1}$, A. Cole ${ }^{1}$, R. Ebinghaus ${ }^{2,3}$, G. Lawson ${ }^{4}$, and W. R. Leaitch ${ }^{1}$ \\ ${ }^{1}$ Air Quality Processes Research Section, Environment Canada, 4905 Dufferin St., Toronto, Ontario, M3H 5T4, Canada \\ ${ }^{2}$ Leuphana University Lüneburg, Institute of Sustainable \& Environmental Chemistry (ISEC), Scharnhorststr. 1/13, \\ 21335 Lüneburg, Germany \\ ${ }^{3}$ Helmholtz-Zentrum Geesthacht, Institute of Coastal Research, Department for Environmental Chemistry,Max-Planck-Str. 1, \\ 21502 Geesthacht, Germany \\ ${ }^{4}$ Environment Canada, Science and Technology Branch, 867 Lakeshore Rd, Burlington, Ontario, L7R 4A6, Canada
}

Correspondence to: A. Steffen (alexandra.steffen@ec.gc.ca)

Received: 29 May 2013 - Published in Atmos. Chem. Phys. Discuss.: 26 June 2013

Revised: 6 December 2013 - Accepted: 23 January 2014 - Published: 3 March 2014

\begin{abstract}
Ten years of atmospheric mercury speciation data and 14 years of mercury in snow data from Alert, Nunavut, Canada, are examined. The speciation data, collected from 2002 to 2011, includes gaseous elemental mercury (GEM), particulate mercury $(\mathrm{PHg})$ and reactive gaseous mercury (RGM). During the winter-spring period of atmospheric mercury depletion events (AMDEs), when GEM is close to being completely depleted from the air, the concentration of both PHg and RGM rise significantly. During this period, the median concentrations for PHg is $28.2 \mathrm{pgm}^{-3}$ and RGM is $23.9 \mathrm{pgm}^{-3}$, from March to June, in comparison to the annual median concentrations of 11.3 and $3.2 \mathrm{pgm}^{-3}$ for $\mathrm{PHg}$ and RGM, respectively. In each of the ten years of sampling, the concentration of PHg increases steadily from January through March and is higher than the concentration of RGM. This pattern begins to change in April when the levels of $\mathrm{PHg}$ peak and RGM begin to increase. In May, the high PHg and low RGM concentration regime observed in the early spring undergoes a transition to a regime with higher RGM and much lower PHg concentrations. The higher RGM concentration continues into June. The transition is driven by the atmospheric conditions of air temperature and particle availability. Firstly, a high ratio of the concentrations of PHg to RGM is reported at low temperatures which suggests that oxidized gaseous mercury partitions to available particles to form PHg. Prior to the transition, the median air temperature is $-24.8^{\circ} \mathrm{C}$ and after the transition the median air temperature is $-5.8^{\circ} \mathrm{C}$. Secondly, the high $\mathrm{PHg}$ concentrations occur
\end{abstract}

in the spring when high particle concentrations are present. The high particle concentrations are principally due to Arctic haze and sea salts. In the snow, the concentrations of mercury peak in May for all years. Springtime deposition of total mercury to the snow at Alert peaks in May when atmospheric conditions favour higher levels of RGM. Therefore, the conditions in the atmosphere directly impact when the highest amount of mercury will be deposited to the snow during the Arctic spring.

\section{Introduction}

Attention to mercury has increased in the scientific community over the past two decades because of the interesting springtime atmospheric chemistry in the high Arctic and its potential impact on the environment. Since there are no local sources of anthropogenic mercury in the Arctic, its presence is thought to be due to long range transport from Asia, Russia, North America and Europe (Durnford et al., 2010). The atmospheric processes that dominate the springtime oxidation and deposition of mercury may also lead to the deposition of some of this long range transported mercury onto the Arctic surface. It has been demonstrated that, during the polar spring, gaseous elemental mercury (GEM) oxidizes to shorter lived mercury species known as reactive gaseous mercury (RGM) (Schroeder et al., 1998; Lindberg et al., 2001). RGM can exist in the air as a gas, deposit to the surface or 
be adsorbed to particles as particulate mercury (PHg) (Sheu and Mason, 2004; Lindberg et al., 2007; Steffen et al., 2008; Amos et al., 2012). Many studies have reported the decrease in GEM and a concurrent increase in oxidized mercury (PHg and RGM) and the connection of this chemistry to spring time ozone and halogen chemistry (Lindberg et al., 2001; Lindberg et al., 2002; Aspmo et al., 2005; Kirk et al., 2006; Cobbett et al., 2007; Simpson et al., 2007; Dastoor et al., 2008; Steffen et al., 2008; Steen et al., 2011). While atmospheric mercury speciation data in the Arctic air have been collected at several sites (Aspmo et al., 2005; Sprovieri et al., 2005; Kirk et al., 2006; Skov et al., 2006; Cobbett et al., 2007; Steen et al., 2011; Moore et al., 2012; Cole et al., 2013; Steffen et al., 2013; Brooks et al., 2006), few longterm (more than 5 years) mercury speciation measurements at temperate regions have been published and the Alert data set is the only such Arctic data set (Cole et al., 2013).

Alert is a high Arctic site, located at the tip of Ellesmere Island, Nunavut, Canada. Long-term atmospheric measurements of GEM have been undertaken since 1995 (Schroeder et al., 1998; Cole and Steffen, 2010) and speciation data have been collected since 2002. The unique GEM annual signature from Alert has been previously published (Schroeder et al., 1998; Steffen et al., 2005; Cobbett et al., 2007; Cole and Steffen, 2010) showing northern hemispheric background levels in the fall and winter, lower concentrations in the spring and higher concentrations in the summer. The lifetime of atmospheric mercury depends on its chemical form and is considered to be GEM $\gg \mathrm{PHg}>\mathrm{RGM}$ (Schroeder and Munthe, 1998). The dry deposition velocities of these species have been modelled to be RGM > PHg > GEM (Zhang et al., 2009). The partitioning between these $\mathrm{Hg}$ species depends on geographical location and chemistry with GEM being the predominant species in the air in most locations (generally the sum of all $\mathrm{Hg}$ species consists of $98 \%$ GEM, $1.5 \%$ RGM and $0.5 \%$ PHg, Peterson et al., 2009). However, in the Arctic (and Antarctic) this partitioning changes during the spring months; at Alert for example, to 88.5\% GEM, 4.5\% RGM and $7 \% \mathrm{PHg}$ (using the mean Alert mercury concentration data from 2002 to 2011) or $95.6 \%$ GEM, $2 \%$ RGM and $2.4 \% \mathrm{PHg}$ (using median concentrations). It is well known that a series of photochemically initiated reactions can oxidize GEM to an $\mathrm{Hg}$ (II) inorganic species (Simpson et al., 2007; Ariya et al., 2008; Obrist et al., 2011). These reactions result in atmospheric mercury depletion events (AMDEs) and refer to the depletion of GEM from the troposphere. This loss has been explained as conversion of GEM to other mercury species and/or a loss to the snow surface (Steffen et al., 2008).

Currently, the actual chemical identities of RGM and PHg are not well determined, they are operationally defined as the fraction of gaseous mercury that can be separated from the air by a $\mathrm{KCl}$ coated denuder and mercury associated with particles collected on a quartz filter, respectively (Sheu and Mason, 2004; Gustin and Jaffe, 2010). Analysis methods for
RGM and PHg include separation of the species and quantification as GEM.

Aerosol particles have been studied at Alert since 1980 (Barrie, 1986; Barrie et al., 1989; Gong et al., 1997; Sirois and Barrie, 1999; Sharma et al., 2004). The well-known phenomenon of Arctic haze is due to air masses originating from anthropogenic emission source regions in Eurasia and North America that are transported to and trapped in the Arctic air. The haze primarily consists of sulfate and carbonaceous particles, maximizing in March and April (Sharma et al., 2004; Quinn et al., 2007).

This study reports on an analysis of 10 years of mercury sampling in air and 14 years of mercury sampling of the snow coupled with atmospheric local meteorological and particle measurements collected from Alert. Monthly statistics on this unique data set are presented and an investigation into the distribution of atmospheric mercury speciation at Alert through the spring and what affects mercury deposition is reported.

\section{Methods}

\subsection{Sample location}

Alert, Nunavut, Canada is located at $82.5^{\circ} \mathrm{N}, 62.3^{\circ} \mathrm{W}$, $800 \mathrm{~km}$ from the geographic North Pole. The instrumentation is located at the Dr. Neil Trivett Global Atmospheric Watch (GAW) Observatory on the north-eastern edge of Ellesmere Island. The laboratory is located approximately $8 \mathrm{~km}$ from the shore of the Lincoln Sea and is at an elevation of $195 \mathrm{~m}$ a.s.l. The atmospheric mercury speciation and particulate instruments are located on an outside walk-up tower approximately three and five metres above the ground, respectively. The tables from which the snow samples are collected are located approximately $200 \mathrm{~m}$ south of the laboratory.

\subsection{Atmospheric mercury speciation}

GEM and PHg/RGM (converted to GEM) are analyzed using a Tekran ${ }^{\circledR} 2537 \mathrm{~A} / 1130 / 1135$ automated mercury vapour analyzer system. The methods have been described in detail elsewhere (Landis et al., 2002). In short, air is pulled into the analyzer through a Teflon ${ }^{\circledR}$ coated elutriator and impactor designed to remove particles and snow $>2.5 \mu \mathrm{m}$ at flow rates of $10.0 \mathrm{~L} \mathrm{~min}^{-1}$ (particle size cut-off varies with flow rate). The sample air flows via a $\mathrm{KCl}$ coated quartz denuder to trap RGM in the 1130 unit, and then passes over a quartz particulate filter to trap PHg in the 1135 unit. GEM passes through both the 1130 and 1135 units and is carried into the 2537 analyzer (at a flow rate of $1 \mathrm{~L} \mathrm{~min}^{-1}$ ) for analysis. The GEM concentration is reported as $\mathrm{ng} \mathrm{m}^{-3}$ of mercury (henceforth denoted as [GEM] in this paper). Analysis for PHg and RGM is as follows: first an in-line pyrolyzer is heated to $800^{\circ} \mathrm{C}$. The quartz filter is then heated to desorb the $\mathrm{PHg}$ which is 
sent through the pyrolyzer to thermally decompose all $\mathrm{PHg}$ species into GEM. This GEM is then analyzed by the 2537A instrument. Next the denuder is heated to $600{ }^{\circ} \mathrm{C}$ to release the RGM which passes over the pyrolyzer to break down all RGM to GEM that is analyzed by the 2537A instrument. $\mathrm{PHg}$ and RGM concentrations are reported as $\mathrm{pg} \mathrm{m}^{-3}$ of mercury (henceforth denoted as [PHg] and [RGM], respectively). Mercury free air is passed through the system before and after these desorption cycles as blanks. At Alert, air samples were originally collected for $3 \mathrm{~h}$ to ensure there was enough mercury collected for analysis and, once verified, the sampling time was reduced to $2 \mathrm{~h}$. Rigorous procedures during and after sample collection/analysis have been established for Alert to ensure consistency from year to year and are described in detail by Steffen et al. (2012).

The analytical detection limits of the Tekran ${ }^{\circledR} 2537$ analyzer $\left(<0.1 \mathrm{ng} \mathrm{m}^{-3}\right.$, from the manufacturer, or $0.75 \mathrm{pg}$ of mercury) are more than an order of magnitude below ambient GEM concentrations (typically $>1 \mathrm{ng} \mathrm{m}^{-3}$ ). For the $\mathrm{PHg}$ and RGM data collected at Alert, the detection limits are calculated to be $3 \times$ the standard deviation of the two post desorption blanks. The detection limits for PHg and RGM at Alert for each year from 2002 to 2011 are shown in Table 1.

\subsection{Meteorological data}

The air temperature is measured at the GAW station at a $1 \mathrm{~Hz}$ frequency using a Campbell 107F thermistor (USA). Prior to 2004 , relative humidity (RH) was calculated from the dew point measured with a custom Atmospheric Environmental Services Type E dew cell (AES Drawing series 0306) at the Alert station (station \#2400300, 82 $31^{\prime} 4^{\prime \prime} \mathrm{N}, 62^{\circ} 16^{\prime} 50^{\prime \prime} \mathrm{W}$; $30.48 \mathrm{~m}$ ). All RH measurements after 26 June 2004 are from a Vaisala RH sensor (model HMP45C212) at the Alert Climate station $\left(2400305,82^{\circ} 30^{\prime} \mathrm{N}, 62^{\circ} 20^{\prime} \mathrm{W} ; 65.4 \mathrm{~m}\right)$. Data are obtained from the Environment Canada National Climate Data and Information Archive (http://climate.weatheroffice. gc.ca/contacts/index_e.html).

\subsection{Aerosol particle volume and light scattering}

Ambient aerosol is pulled from the outside into the laboratory through a $3 \mathrm{~m}$ long, $10 \mathrm{~cm}$ diameter stainless steel vertical manifold at a flow rate of about $1000 \mathrm{~L} \mathrm{~min}^{-1}$. Particles are sampled out of the manifold from near the centre of the flow stream, about $30 \mathrm{~cm}$ up from the bottom of the manifold. From there, the particles are delivered to the sampling devices through stainless steel tubing. The average total residence time of a particle from when it is collected outside to its measurement point inside is approximately $3 \mathrm{~s}$. Once the particle reaches the analyzer it is approximately at room temperature and has a relative humidity $(\mathrm{RH})$ of less than $50 \%$. Particle size distributions from $20 \mathrm{~nm}$ to $500 \mathrm{~nm}$ are measured with a TSI 3034 Scanning Mobility Particle System (SMPS) which is calibrated on site using monodisperse particles of polystyrene latex and of ammonium sulfate generated with a Brechtel Manufacturing Incorporated (BMI) Scanning Electrical Mobility Spectrometer (SEMS). Particle volume concentrations in the size range of $20-500 \mathrm{~nm}$ are derived from the integration of the SMPS size distribution assuming spherical particles.

Particle volume dry scattering coefficients $\left(\sigma_{\mathrm{sp}}\right)$ in $<1$ and $<10 \mu \mathrm{m}$ sizes are measured by a $3-\lambda$ Integrating Nephelometer (TSI Model 3563). The instrument is calibrated by using high-purity dry $\mathrm{CO}_{2}$ and drift in the calibration is checked weekly. Measurement uncertainties of the TSI nephelometer have been described in detail elsewhere (Anderson and Ogren, 1998; Anderson et al., 1999; Sheridan et al., 2002). The nephelometer data used in this paper are particle volume light scattering coefficients $\left(b_{\text {sca }}\right)$ at $550 \mathrm{~nm}$ wavelength. At that wavelength, most of the light scattering is by particles that are greater than about $100 \mathrm{~nm}$ diameter. From 20042006 there was no upper size cut on particles entering the nephelometer. A $1 \mu \mathrm{m}$ upper size cut was added after 2006, and so the post- $2006 b_{\text {sca }}$ was mostly influenced by particles in the $100 \mathrm{~nm}$ to $1 \mu \mathrm{m}$ size range.

\subsection{Snow sampling}

One litre wide-mouth glass jars are used for sample collection. Until 2002, PTFE lined polypropylene (PP) lids had been used but these were replaced with solid PFA Teflon ${ }^{\circledR}$ lids (Savillex) in 2002. This change was made because the PFA lids were not durable and tended to break in transit resulting in a loss of samples. The snow is collected on tables and the ground located behind the GAW lab. Snow samples are collected on a snow event basis when the local operator is available to collect the sample. There are two tables approximately $1 \mathrm{~m} \times 1 \mathrm{~m}$ each from which the samples are collected. The tables are made of a wooden platform covered with a $1 / 32^{\prime \prime}$ thick PTFE sheet that is attached to the table surrounded by a $1^{\prime \prime} \times 1^{\prime \prime}$ PTFE edge. The platform is mounted on Dexion steel strips and the legs are dug into the tundra for stability. When there is a layer of snow on the tables, three bottles of snow are collected using gloved hands, a PTFE scraper and a scoop made from a PTFE bottle. The snow is collected into a pile with the scraper and scooped into glass jars from the snow tables. The tables are divided into three sections and each area of sample collected is measured. When the samples have been collected, the remainder of snow is scraped off so that the table is left blank and ready to collect the next snowfall. Using a very similar procedure, ground samples are collected close to the tables. The surface snow (approximately $1 \mathrm{~cm}$ deep) is scraped into a pile using a Teflon ${ }^{\circledR}$ scraper. The snow is then scooped into the glass sample jars. Snow samples are kept in the jars in sealed zip-locked bags, in coolers and are kept frozen. The coolers are filled with snow and hand carried/escorted on a military cargo plane and car from Alert to Toronto where they remain frozen until analysis. 
Table 1. Detection limits for each year for annual and springtime speciation measurements and the number of samples represented for each data point from 2002 to 2011 at Alert, Canada. Detection limits are reported in $\mathrm{pg} \mathrm{m}^{-3}$.

\begin{tabular}{lrrrrrrrrrr}
\hline $\begin{array}{l}\text { Detection limit } \\
\left(\mathrm{pg} \mathrm{m}^{-3}\right)\end{array}$ & 2002 & 2003 & 2004 & 2005 & 2006 & 2007 & 2008 & 2009 & 2010 & 2011 \\
\hline Annual & 10.50 & 5.50 & 2.08 & 1.80 & 0.73 & 5.39 & 1.16 & 2.25 & 1.10 & 1.47 \\
Spring & 1.33 & 6.24 & 3.08 & 2.63 & 1.17 & 7.89 & 1.32 & 3.61 & 1.93 & 1.88 \\
\hline No. of samples & & & & & & & & & & \\
\hline Annual & 1954 & 2169 & 3525 & 3130 & 5232 & 4220 & 4262 & 4482 & 3070 & 3711 \\
Spring & 864 & 533 & 916 & 1000 & 1452 & 834 & 1176 & 1262 & 498 & 1208 \\
\hline
\end{tabular}

\subsection{Snow analysis}

The sample jars and lids are cleaned in a multi-stage process: soap bath, concentrated hydrochloric acid, concentrated nitric acid, then air dried in a clean lab. Jars are numbered and pre-weighed before they are packed in coolers and sent to Alert. Blank water is generated using a multi-stage purification process: reverse osmosis, distillation, passage through two Milli-Q systems with UV-digestion. Bromine monochloride $(0.1 \mathrm{~N} \mathrm{BrCl})$ is prepared using low-Hg hydrochloric acid (HCl; JT Baker Instra-analyzed), bromic acid (Sigma) and potassium bromate (Alfa Aesar). Alkaline stannous sulfate is produced from stannous sulfate (Alfa Aesar and Sigma) and low-Hg sodium hydroxide (Anachemia Science).

Prior to analysis, sample jars are weighed and $0.1 \mathrm{~N} \mathrm{BrCl}$ is added to the thawing snow samples to give a final concentration of $0.4 \%$. Total $\mathrm{Hg}$ in the melted snow is determined by direct cold-vapour atomic fluorescence detection after reduction with alkaline stannous sulfate. The detection limits of this method are typically $0.05 \mathrm{pg} \mathrm{mL}^{-1}$, based on $3 \times$ standard deviation of the analytical blanks. The analytical system couples an autosampler (Gilson 222) and an atomic fluorescence detector (Tekran $\left.{ }^{\circledR} 2500\right)$ and uses a chromatography interface and software for signal capture and peak integrations. The phase separator was built in-house and made of PFA Teflon ${ }^{\circledR}$ with a polyethylene gas bubbler and actively pumped liquid inlet and outlets. A gas phase drier (Nafion) removes water from the sample gas before it passes into the AFS detector.

Quality assurance and control samples included laboratory, bottle, trip and field blanks. In all cases, $250 \mathrm{~mL}$ of ultrapure blank water is added to the blank jars, along with $0.1 \mathrm{~N}$ $\mathrm{BrCl}$ to give the same concentration as the samples $(0.4 \%)$. The $250 \mathrm{~mL}$ value is selected because it was close to the average volume of the melted snow samples. Standard reference water is analyzed alongside samples during analyses. All samples are pre-screened with $10 \mathrm{~mL}$ single samples to determine general THg concentrations. The samples are split into low and high samples to fit calibration standards with equivalent concentration ranges. The final analytical measurements determined samples as duplicates or triplicates and spike re- coveries were determined every 8 to 10 samples. Analytical blank results are not subtracted from sample results, since the blank water is independent of the sample results and reagents used have been determined to be below the detection limits of the method. These blank results are used as a base value for the various other blanks determined. Field blank averages are used to correct sample results, after conversions to average mass per jar values.

\section{Results and discussion}

\subsection{Long-term speciation data}

Gaseous elemental mercury (GEM), reactive gas phase mercury $(\mathrm{RGM})$ and particulate mercury $(\mathrm{PHg})$ concentration measurements from Alert, Canada, from 2002 to 2011 are shown in Fig. 1. Instrumental problems during 2003, 2006 and 2010 are responsible for the incomplete data sets for those years. The annual signature of mercury species repeats from year to year. Figure 2 shows box plots of the monthly concentrations of GEM, RGM and PHg over the 10 year period. The middle line in the box indicates the median concentration; the bottom and top of the box represent the 25th and 75th percentiles; the whiskers above and below the box indicate the 90th and 10th percentiles and the dots indicate the 95th and 5th percentiles. A distinct annual cycle for all 3 species is highlighted in this figure.

Annual statistics of $[\mathrm{PHg}]$ and $[\mathrm{RGM}]$ show considerable variability among the years. The monthly and overall statistics are presented in Table 2. The PHg and RGM median concentrations for the 10 year period are 11.3 and $3.2 \mathrm{pg} \mathrm{m}^{-3}$, respectively, but as is clear from Fig. 2, there are considerable changes in the concentrations throughout the year. $[\mathrm{PHg}]$ is very low in the months June through October (median $<8.4 \mathrm{pg} \mathrm{m}^{-3}$ ) but begins to increase in November through February (median range $\sim 9-42 \mathrm{pg} \mathrm{m}^{-3}$ ). This pattern is seen each year and is likely a product of aerosol transport from southern latitudes, commonly referred to as Arctic haze (Barrie, 1986; Sharma et al., 2013). The springtime chemistry is evident in the elevated $[\mathrm{PHg}]$ levels during March to May (median range 21-103 $\mathrm{pg} \mathrm{m}^{-3}$ ). In contrast, 


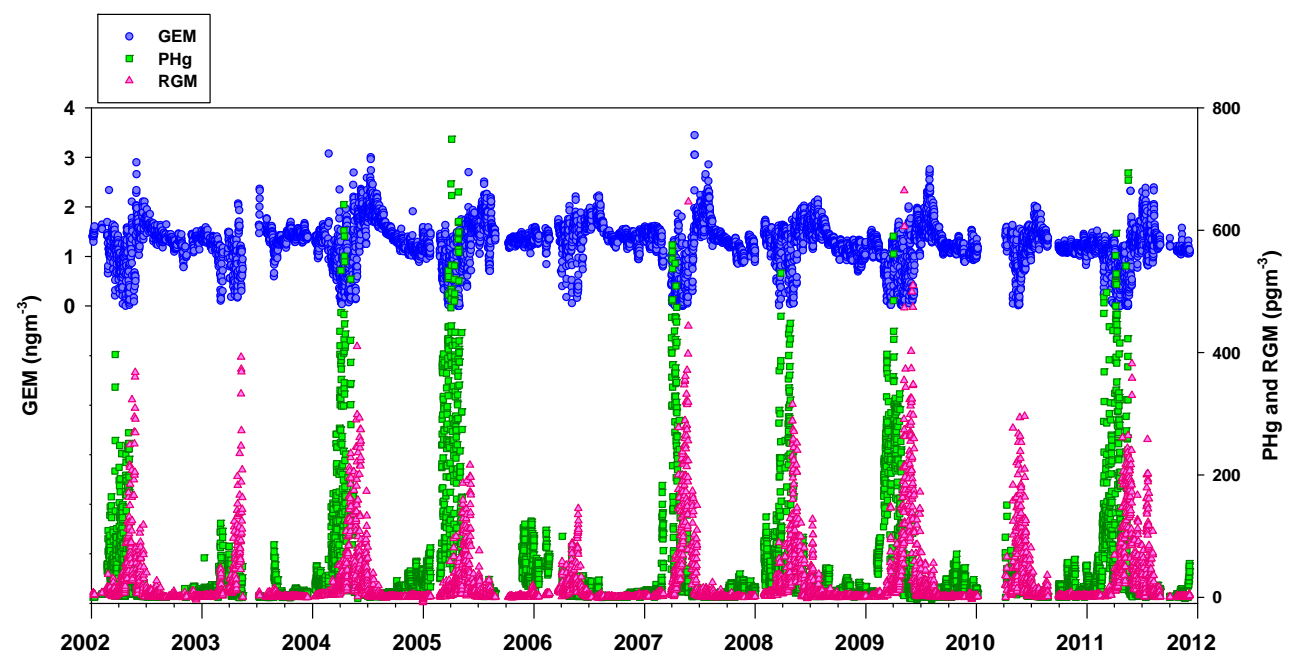

Fig. 1. Six hourly averaged data for gaseous elemental mercury (GEM-blue), particulate mercury (PHg-green) and reactive gaseous mercury (RGM-pink) from 2002 to 2011 at Alert Nunavut, Canada.

[RGM] is very low from August to February (median range $\left.0.7-5.3 \mathrm{pg} \mathrm{m}^{-3}\right)$, slightly elevated in the months March and July (median 7.4 and $4.6 \mathrm{pg} \mathrm{m}^{-3}$, respectively) and high from April to June (median range $17-100 \mathrm{pg} \mathrm{m}^{-3}$ ). It has been reported that AMDEs stop when the temperature is sustained above $0{ }^{\circ} \mathrm{C}$ (Steffen et al., 2005); however, there appears to be production of RGM well into July where air temperatures are above $0^{\circ} \mathrm{C}$. The origin of these annually occurring higher levels of RGM in July is unclear since it is unlikely to be due to AMDE chemistry because temperatures are above $0{ }^{\circ} \mathrm{C}$ during this month. Finally, Fig. 2 shows that the previously reported decrease in [GEM] in March (Cole and Steffen, $2010)$ is concurrent with a notable increase in $[\mathrm{PHg}]$ followed by an increase in $[\mathrm{RGM}]$ in May. $[\mathrm{PHg}]$ reaches a maximum in April and then decreases in subsequent months. In May, [RGM] is highest and it decreases in June when [GEM] begins to increase again. Cobbett et al. (2007) reported a transition (or shift) in the concentration of predominant species of measured mercury in the air from PHg to RGM in the spring of 2005 at Alert. We report here that this transition occurs each year around the same time (within a 2 week period) for the 10 years of measurements. Transitions from PHg to RGM about the same time of the year were also observed in 2004 at Churchill, Canada (Kirk et al., 2006), and at Ny-Ålesund in 2007/08 (Steen et al., 2011). Associations of PHg and RGM with temperature, relative humidity and aerosol particle concentrations measured at Alert during March to June are examined next. Future investigations into the spring-summer cycling of PHg and RGM will be important to offer more detailed explanations of these associations.

\subsection{Factors affecting the atmospheric transition of [PHg] to [RGM]}

Previous field and modelling studies have suggested that factors such as specific humidity, air temperature, wind speed, air mass origin and aerosol particle loadings may impact the partitioning of mercury species (Cobbett et al., 2007; Rutter and Schauer, 2007a, b; Steffen et al., 2008; Steen et al., 2011; Amos et al., 2012). In this study we investigate what can be learned from a study of the composition of the air as observed at Alert. It has to be realized that what we see is the result of chemico-physical processes that occurred upwind of Alert. The origin of air masses travelling to Alert have been previously studied in depth and revealed that the large majority of mercury and ozone depletion events occur when the wind direction is between $315^{\circ}$ and $90^{\circ}$ (i.e. from over the Arctic Ocean) (Cole and Steffen, 2010) and from the North Pole to the Kara Sea (Bottenheim and Chan, 2006). Another study from Alert reported that the predominant wind direction in 2005 was from the south-southwest direction; yet, when depletion events occurred, the winds tended to emerge from the north (Cobbett et al., 2007).

Here relative humidity $(\mathrm{RH})$, air temperature and particle concentration are investigated for their possible roles in the partitioning of mercury species at Alert during the spring. Monthly box and whisker plots of air temperature (top) and RH (bottom) for years 2002-2011 and 2004-2011, respectively, are shown in Fig. 3. The median RH increases substantially from April to May. Before the transition of high $[\mathrm{PHg}]$ to high [RGM], the median (April) $\mathrm{RH}$ is $74 \%$ and after the transition the RH (May) is $85 \%$. It has been suggested that a threshold of $75 \%$ RH marks a decrease in [PHg] in the Arctic spring (Steffen et al., 2013). Since RH is temperature dependant and describes the water content relative 
Table 2. Descriptive statistics of [PHg] (top) and [RGM] (bottom) for monthly data and overall data between 2002 and 2011 at Alert, Canada. All concentrations for mean, median, standard deviation (SD) and maximum are reported in $\mathrm{pg} \mathrm{m}^{-3}$. Number represents the number of data points included in the statistics. Mean monthly air temperature is reported in ${ }^{\circ} \mathrm{C}$.

\begin{tabular}{|c|c|c|c|c|c|c|}
\hline $\mathrm{PHg}$ & Mean & Median & SD & Maximum & Number & Air temp \\
\hline January & 20.4 & 13.39 & 18.08 & 99.26 & 1023 & -28.0 \\
\hline February & 50.26 & 41.87 & 53.31 & 520.54 & 926 & -30.3 \\
\hline March & 136.67 & 102.60 & 110.38 & 541.51 & 1175 & -30.5 \\
\hline April & 149.58 & 80.56 & 154.48 & 748.69 & 1710 & -22.8 \\
\hline May & 45.46 & 21.15 & 71.74 & 698.03 & 1688 & -10.6 \\
\hline June & 12.76 & 8.40 & 15.45 & 153.33 & 1517 & -0.18 \\
\hline July & 7.36 & 4.66 & 7.10 & 40.98 & 1638 & +4.3 \\
\hline August & 6.22 & 3.38 & 9.55 & 85.76 & 1642 & +2.2 \\
\hline September & 5.30 & 4.54 & 5.39 & 48.26 & 924 & -7.39 \\
\hline October & 10.25 & 5.46 & 12.37 & 70.40 & 1194 & -16.5 \\
\hline November & 15.25 & 9.61 & 17.46 & 122.30 & 1297 & -23.2 \\
\hline December & 18.35 & 9.58 & 21.91 & 135.62 & 1349 & -27.4 \\
\hline Overall & 41.3 & 11.3 & 82.3 & 748.69 & 16083 & \\
\hline RGM & Mean & Median & SD & Maximum & Number & \\
\hline January & 2.36 & 2.13 & 1.22 & 7.79 & 942 & \\
\hline February & 5.25 & 4.98 & 2.92 & 37.57 & 837 & \\
\hline March & 11.35 & 7.40 & 15.63 & 220.56 & 1147 & \\
\hline April & 33.96 & 22.20 & 35.78 & 331.87 & 1714 & \\
\hline May & 120.11 & 99.88 & 94.67 & 877.85 & 1630 & \\
\hline June & 41.09 & 16.76 & 62.13 & 718.02 & 1516 & \\
\hline July & 14.78 & 4.60 & 30.77 & 260.95 & 1687 & \\
\hline August & 4.35 & 1.46 & 8.75 & 108.82 & 1732 & \\
\hline 1-7 September & 1.01 & 0.71 & 1.37 & 13.93 & 1069 & \\
\hline October & 0.88 & 0.70 & 0.90 & 7.99 & 1452 & \\
\hline November & 1.08 & 0.94 & 0.99 & 10.71 & 1451 & \\
\hline December & 1.86 & 1.71 & 1.98 & 20.72 & 1410 & \\
\hline Overall & 22.6 & 3.17 & 51.99 & 877.85 & 16587 & \\
\hline
\end{tabular}

Note minimum values for PHg ranged from 0 to 1.6 and for RGM 0 to 0.4 .

to saturation, absolute water content (AWC) is also plotted (middle). In Fig. 3, both RH and AWC follow the same pattern with temperature throughout the year and a similar significant increase in both parameters is observed from March to May. It is conceivable that the transition of PHg to RGM from April to May could be related to water absorption by aerosols. Holmes et al. (2009) suggested that at low RH the chloride content of sea salt aerosols is highest and thus may factor into RGM uptake by particles. While RH may have an impact on the transition, we suggest that other factors play a stronger role as described below.

The dependence of the transition on the air temperature was investigated by looking at the ratio of $\mathrm{PHg}$ to $\mathrm{RGM}$ as follows: $\mathrm{Hg}(\mathrm{f})=[\mathrm{PHg}] /([\mathrm{PHg}]+[\mathrm{RGM}])(\mathrm{f}$ indicates fraction). Regressions of air temperature vs. $\mathrm{Hg}(\mathrm{f})$ (Fig. 4) indicate that a higher $\mathrm{Hg}(\mathrm{f})$ is associated with colder temperatures. The linear regression $r^{2}$ values and slopes for each year from February to June are shown in Fig. 4. For this part of the study, data from the years 2003, 2006, 2007 and 2010 are not included because of large data gaps. The results derived in Fig. 4 are in keeping with the laboratory findings of Rutter and Schauer (2007b) and the later modelling results of Amos et al. (2012) who reported a linear relationship between the logarithm of inverse gas to particle partitioning (for reactive mercury) and inverse air temperature. The former study's data was limited to a minimum air temperature of $-3^{\circ} \mathrm{C}$ and the latter used temperatures down to $-16.7^{\circ} \mathrm{C}$; here the temperature ranges down to $-40^{\circ} \mathrm{C}$. Moreover, our data cannot be directly compared with these two studies as there are no appropriate particle data available from Alert to calculate a particle surface area in order to normalize the PHg over differently sized surfaces. The calculated slopes from linear regression analysis of this data are similar (see Fig. 4) which indicates that the relationship between the air temperature and $\mathrm{Hg}(\mathrm{f})$ is similar each year. In years when this relationship appears not to be significant (2005 and 2008) a high $\mathrm{Hg}(\mathrm{f})$ at temperatures between -5 and $5{ }^{\circ} \mathrm{C}$ is observed due to anomalously high PHg concentrations. We have no explanation for the elevated $[\mathrm{PHg}]$ for these years at this time. Cole and Steffen (2010) reported a relationship between air temperature 

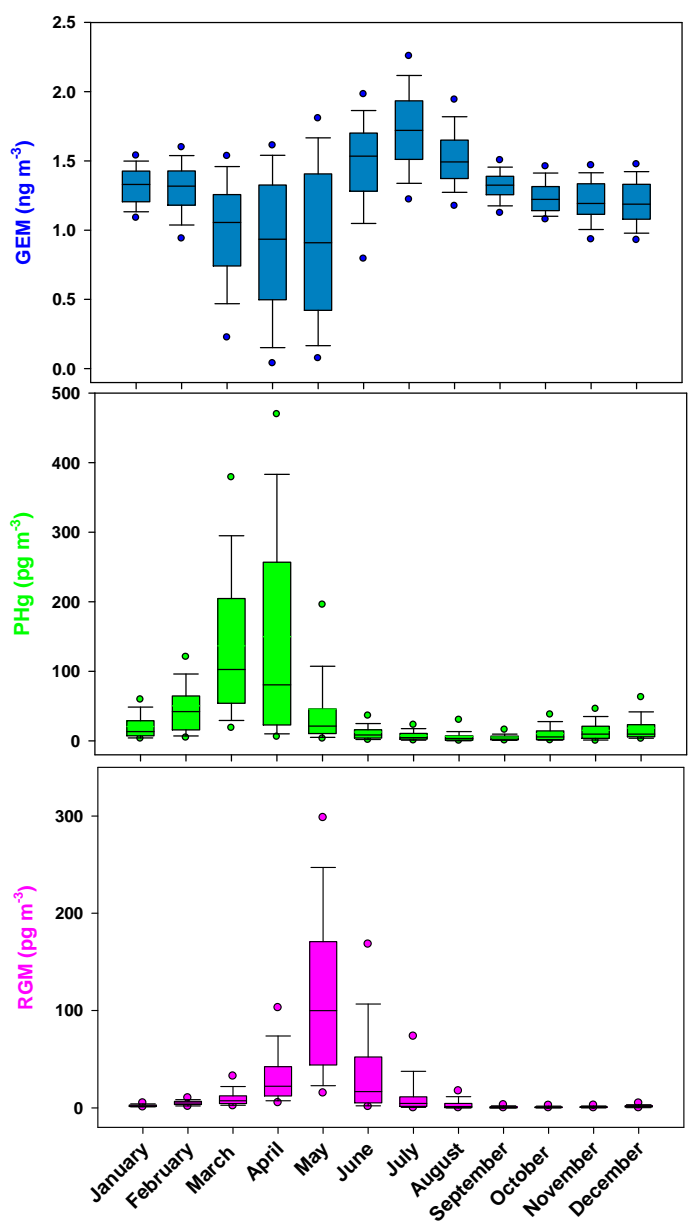

Fig. 2. Box and whisker plots of monthly gaseous elemental mercury (GEM-blue), particulate mercury (PHg-green) and reactive gaseous mercury (RGM-pink) from Alert, 2002-2011. GEM is in $\mathrm{ng} \mathrm{m}^{-3}$ and PHg and RGM are in $\mathrm{pg} \mathrm{m}^{-3}$. Centre line in the box represents the median value, the boundaries of the box represent the 25 th and 75th percentiles, the whiskers represent the 10th and 90th percentile and the dots represent the 5 th and 95 th percentile.

and the frequency of depletion events. They reported that there were higher frequencies of depleted GEM reported in March when temperatures were between -40 and $-45^{\circ} \mathrm{C}$ and between -25 and $-20^{\circ} \mathrm{C}$ in May and suggested that the latter temperature may be related to the initiation of bromine chemistry but did not arrive at a firm explanation for this relationship. Before the transition (March to April), when $\mathrm{Hg}(\mathrm{f}$ ) is greater than 0.5 (predominantly $\mathrm{PHg}$ ), the median air temperature is $-24.8^{\circ} \mathrm{C}$ and after the transition, when $\mathrm{Hg}(\mathrm{f})$ is less than 0.5 (predominantly RGM), the median air temperature is $-5.8^{\circ} \mathrm{C}$. Our results show that $\mathrm{PHg}$ is predominant at lower temperatures. We suggest that the lower temperatures drive the partitioning of oxidized mercury from RGM towards $\mathrm{PHg}$, rather than particles arriving at Alert in the spring containing high levels mercury from their source region. The average temperature during the week of transition
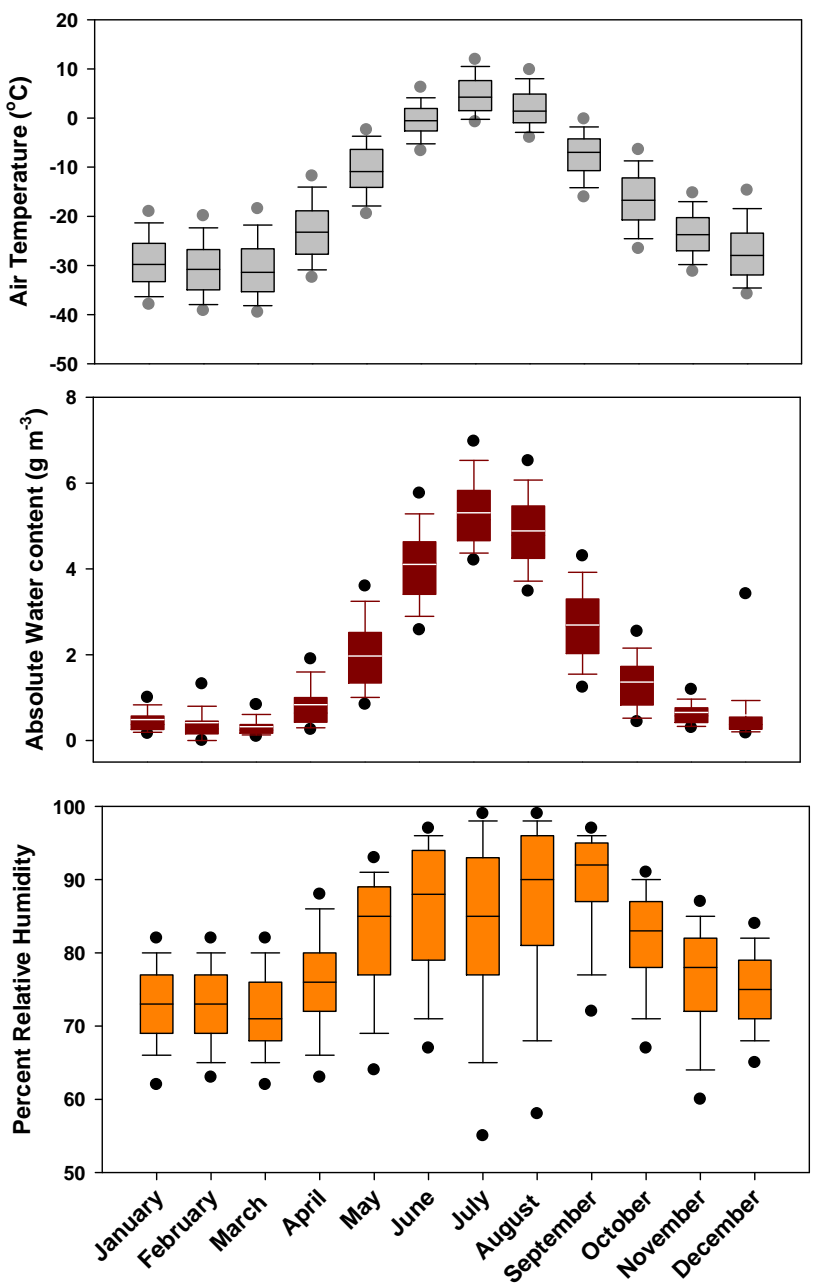

Fig. 3. Box and whisker plots of air temperature, absolute water content (AWC) and percent relative humidity (RH) data from Alert. (Air temperature and AWC are data from 2002-2011 and RH from 2004-2011). Centre line in the box represents the median value, the boundaries of the box represent the 25 th and 75 th percentiles, the whiskers represent the 10th and 90th percentile and the dots represent the 5 th and 95 th percentile.

for all the years, except 2003 and 2010 , is $-15.6 \pm 2.8^{\circ} \mathrm{C}$. Indeed, modelling studies have predicted that in colder air masses the predominant $\mathrm{Hg}$ (II) fraction will be $\mathrm{PHg}$ rather than RGM (Amos et al., 2012). We conclude from the results of our long-term measured data that temperature is a significant driver in the transition of PHg to RGM at Alert during the spring.

The potential impact of the atmospheric aerosol loading on the transition from a predominant PHg to predominat RGM regime is also considered. The aerosol is represented here in two ways: (1) using the particle light scattering measurements from the nephelometer, which is directly related to the surface area of the submicron aerosol; and (2) the volume concentration of the sub-500 nm diameter particles, which is 


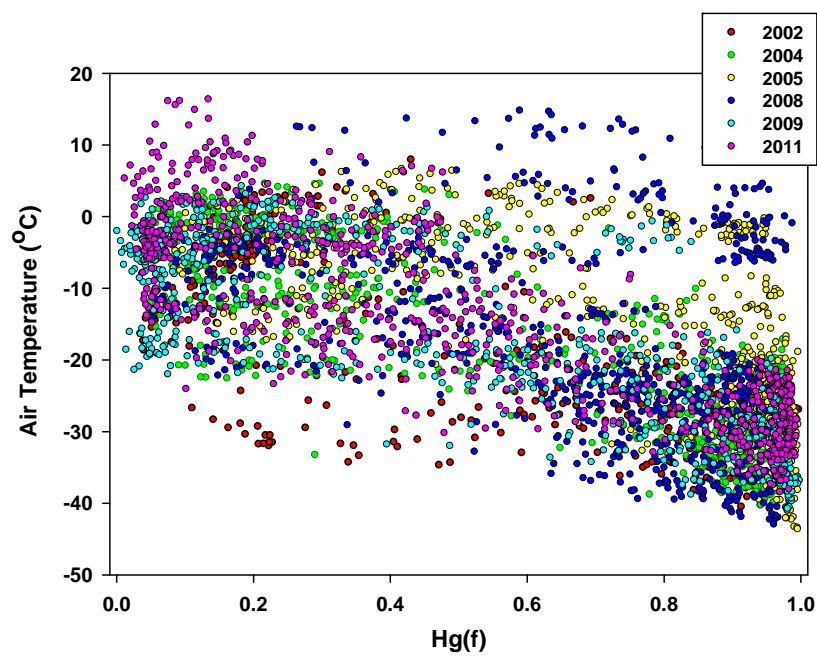

Fig. 4. Linear regression of air temperature vs. particulate $\mathrm{Hg}$ fraction for March to June time period $($ ratio $\mathrm{Hg}(\mathrm{f})=[\mathrm{PHg}] /([\mathrm{PHg}]+$ [RGM])). Slopes: 2002: -27.7; 2004: -29.4; 2005: -29.4; 2008: -16.5 ; 2009: -26.7 ; 2011: $-32.4 R^{2}$ values: 2002: 0.56; 2004 : 0.64; 2005:0.45; 2008: 0.12; 2009: 0.58; 2011: 0.72. Years 2003, 2006, 2007 and 2010 are not included due to large data gaps.

proportional to the mass concentration of the aerosol. The light scattering data are available from 2004 to 2009, whereas the volume concentration data are only available for 2011 at this time. For the long-lived aerosol measured at Alert, these two quantities are proportional to each other. Figure 5 shows monthly box and whisker plots of the particle light scattering coefficient $\left(b_{\text {sca }}\right)$ at $550 \mathrm{~nm}$ wavelength (yellow boxes) and $\mathrm{Hg}(\mathrm{f})$ (grey boxes) for January to June. From January to April both $b_{\text {sca }}$ and $\mathrm{Hg}(\mathrm{f})$ are relatively steady. In May, $\mathrm{Hg}(\mathrm{f})$ decreases to lower values concurrent with a significant decrease in the $b_{\text {sca. }}$. The slight increase in $\operatorname{Hg}(\mathrm{f})$ in June is curious and may be due to low $[\mathrm{PHg}]$ and $[\mathrm{RGM}]$ levels, in comparison to the high values in the previous months, (Table 2) that may lead to large uncertainties and thereby skew the ratio of $\mathrm{Hg}(\mathrm{f})$. Figure 6 shows $[\mathrm{PHg}]$ as a function of the total volume concentration of particles less than $500 \mathrm{~nm}$ for hourly averages during March through June, 2011. These results suggest that $\mathrm{PHg}$ is associated with the higher particle volumes in March and April, May is a transition month to lower particle volume and June shows no association with $\mathrm{PHg}$. As expected, this result is consistent with the trend of $b_{\text {sca }}$ and $\mathrm{Hg}$ (f) in Fig. 5, indicating that a larger $\mathrm{Hg}(\mathrm{f})$ is associated with higher concentrations of particle surface area and volume. Since PHg is believed to result from RGM adhering to particles in the air (Sheu and Mason, 2004) it is likely that the presence of more particle surface and volume may contribute to the shift of [RGM] to [PHg] during January to April at Alert. The higher particle volume concentrations during January to April are linked with Arctic haze (Barrie, 1986; Sharma et al., 2013) and we conclude that the presence of Arctic haze is a significant contributor to the in-

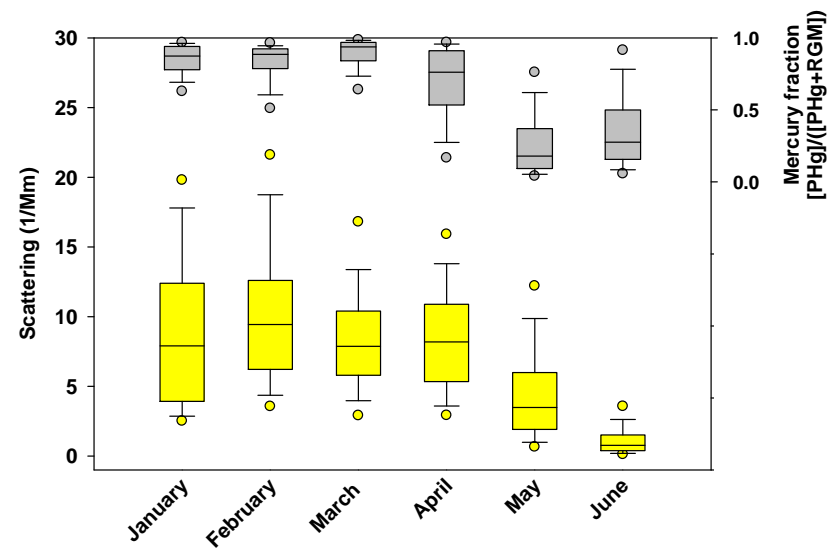

Fig. 5. Monthly box and whisker plot of scattering $\left(b_{\text {sca }}\right)$ and mercury fraction data from Alert. Nephelometer data is in $\left(\mathrm{Mm}^{-1}\right)$ for $550 \mathrm{~nm}$ (yellow) from January to June 2004 to 2009. Mercury fraction data is unitless and is from January to June 2002 to 2011. Centre line in the box represents the median value, the boundaries of the box represent the 25 th and 75 th percentiles, the whiskers represent the 10th and 90th percentile and the dots represent the 5th and 95th percentile.

creased levels of PHg during this period either by offering a surface for partitioning processes rather than particles containing mercury arriving from source regions. This is not the first report of an influence of Arctic haze on mercury: Douglas and Sturm (2004) linked mercury levels and Arctic haze in the snow around northern Alaska. Other aerosols such as sea salts and ice crystals are also common during the spring at Alert. Both these aerosols are effective scavengers of RGM and have been associated with elevated levels of PHg and $\mathrm{Hg}$ in the snow (Rutter and Schauer, 2007a; Douglas et al., 2008; Malcolm et al., 2010; Steffen et al., 2013). Coarse particle $\mathrm{Na}^{+}$, mostly sea salt derived, is elevated in February and at the beginning of March at Alert (Leaitch et al., 2014) but decreases in April. Currently, there are no ice crystal data available from Alert. The partitioning of gas-phase mercury onto particles can depend on the composition of the aerosol (Rutter and Schauer, 2007a) and particles containing sodium nitrate and sea salt components have shown the highest partition coefficients. Each year, $[\mathrm{PHg}]$ levels in the air at Alert begin to increase in March and reach a maximum in April. This pattern is consistent with increased levels of sea salts and Arctic haze particles at the same time and location. Further study is required to identify which types of particles dominate both the change in atmospheric mercury species and deposition of mercury in the spring.

\subsection{Mercury in snow at Alert}

Mercury can be deposited onto the snow and ice surfaces enabling its distribution into the environment. Several studies have been reported on the deposition and fate of mercury on snow and ice surfaces (Boutron et al., 1998; Lu et 


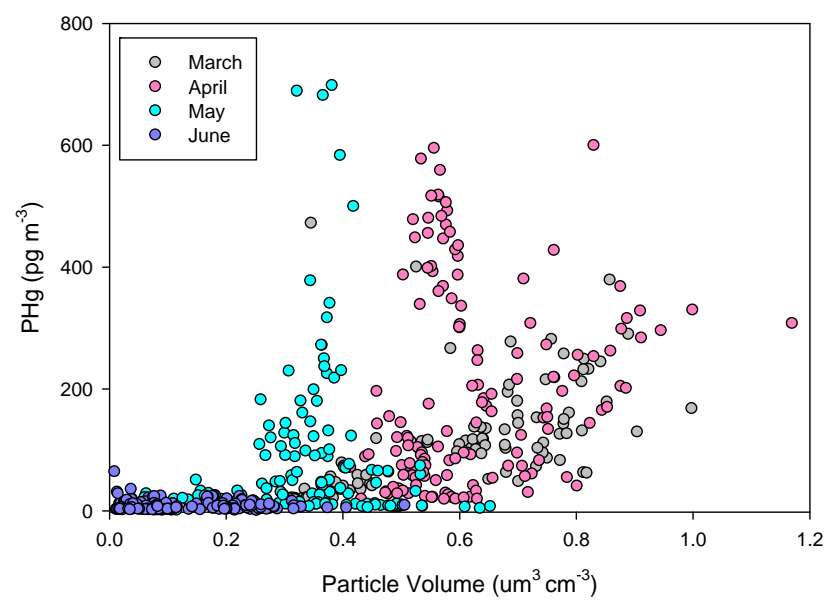

Fig. 6. Particulate mercury (PHg) concentration $\left(\mathrm{pg} \mathrm{m}^{-3}\right)$ as a function of total volume concentration of particles $(<500 \mathrm{~nm})$ for the months March, April, May and June 2011 at Alert, Canada.

al., 2001; Lalonde et al., 2002; Dommergue et al., 2003a, b, 2009; Ariya et al., 2004; Douglas and Sturm, 2004; Ferrari et al., 2004a, b, 2005; Douglas et al., 2005, 2008, 2012; Fitzgerald et al., 2005; Lahoutifard et al., 2005; St. Louis et al., 2005; Kirk et al., 2006; Constant et al., 2007; Poulain et al., 2007; Outridge et al., 2008; Poissant et al., 2008; Steffen et al., 2008; Carignan and Sonke, 2010; Durnford and Dastoor, 2011; Durnford et al., 2012), but the long-term snow data presented here are unique.

All three forms of mercury can be removed from the atmosphere and deposited onto snow and ice. While the deposition velocity of GEM is much lower than that of RGM and $\mathrm{PHg}$ (Zhang et al., 2009), the concentration of GEM in the air is quite high in comparison to other two species and, as a result, GEM could be present in the snow samples (Lin, 2006). However, a review of mercury behaviour in snow concluded that any deposited GEM would immediately be re-emitted (Durnford and Dastoor, 2011) and thus we do not consider GEM to be a significant portion of mercury in the snow samples. Further, a large amount of the GEM in the air during the spring is converted to RGM and PHg and thus we only consider these mercury species for the purposes of this analysis of the impact of AMDEs on the mercury levels in the snow at Alert. In an analysis of the fate of deposited mercury in the snow pack, Durnford and Dastoor (2011) suggested that the PHg deposited to snow is likely to remain in the snow pack but that deposited RGM can undergo several processes including photo reduction and re-emission and additional reduction/oxidation processes in the snow and thus its fate in the snow is uncertain.

Since 1998, snow samples have been collected at Alert in the spring just after a snow event. The number of samples has depended on the number of snow events occurring in a given year and on local operator availability to sample the snow. Figure 7 shows box and whisker plots of the con- centrations of $\mathrm{Hg}$ from Alert (1998-2011) in the snow (in $\mathrm{pg} \mathrm{g}^{-1}$ ) from both the table (top) and ground samples (bottom). It can be seen that significantly lower $\mathrm{Hg}$ concentrations are observed in the ground samples in comparison to the table samples. Snow sampling was undertaken to investigate springtime chemistry and thus occurred only during the months of February to June. To the authors' knowledge, this is the only data set of its kind from the Arctic. Collecting snow on a table in this manner is believed to give a reasonable measure of $\mathrm{Hg}$ that is removed from the atmosphere by snow. Surface samples are generally collected from the first $1 \mathrm{~cm}$ of the snow pack but accurately limiting the sampling to that level is challenging and in any case may well contain some older snow which would bias the obtained concentrations of its components. Furthermore, surface/ground snow samples can be compromised by contribution from blowing snow, multiple snow events and loss of deposited material to deeper layers of the snow pack. We suggest that the use of a snow table as used in our study is a superior method of snow sampling over a long time period and in what follows we only use the snow table data.

Figure 7 shows the monthly distribution of $\mathrm{Hg}$ in snow from February to June from 1998 to 2011. A small but increasing amount of $\mathrm{Hg}$ in the snow is observed in February, March and April. This is followed by a peak in the levels in May and then decrease in June. There have been reports of similar observations from short-term field studies, or over shorter time periods (Lu et al., 2001; Durnford and Dastoor, 2011) but nothing as extensive as that presented here.

The relationship between the level of $\mathrm{Hg}$ in the snow and the $\mathrm{Hg}$ in the atmosphere (as RGM and $\mathrm{PHg}$ ) is explored in Fig. 8. As indicated before we do not include GEM in this analysis because it is believed to be rapidly re-emitted from the snow. In this figure the mercury concentration in snow (2002-2011) is plotted together with PHg and RGM concentrations from February to June (averaged for each Julian day for all data from 2002 to 2011). It can be seen that during the $[\mathrm{PHg}]$ to $[\mathrm{RGM}]$ transition in the atmosphere, there is an increase in $\mathrm{Hg}$ levels in the snow. This was found to repeat each year, without fail, when snow samples were collected over the ten-year period. During the beginning of the transition period, when both PHg and RGM are present, the levels of mercury in the snow begin to increase considerably. Subsequently, the levels of mercury in snow keep rising (and falling) concurrently with [RGM]. We conclude that the highest deposition of mercury to the snow in the Arctic depends on what form of mercury is present in the atmosphere. As shown in Fig. 8, mercury levels in the snow begin to significantly increase around day 113 (towards the end of April) where $[\mathrm{PHg}]$ and $[\mathrm{RGM}]$ are $\sim 150$ and $40 \mathrm{pg} \mathrm{m}^{-3}$, respectively. The highest mercury in snow was reported from days 128-131 where [PHg] and [RGM] were $\sim 70$ and $\sim 150 \mathrm{pg} \mathrm{m}^{-3}$, respectively. The decrease in $\mathrm{PHg}$, and drop in particle numbers, in May coincide with the initial increase of $\mathrm{Hg}$ in the snow. Even though $\mathrm{PHg}$ is scavenged 

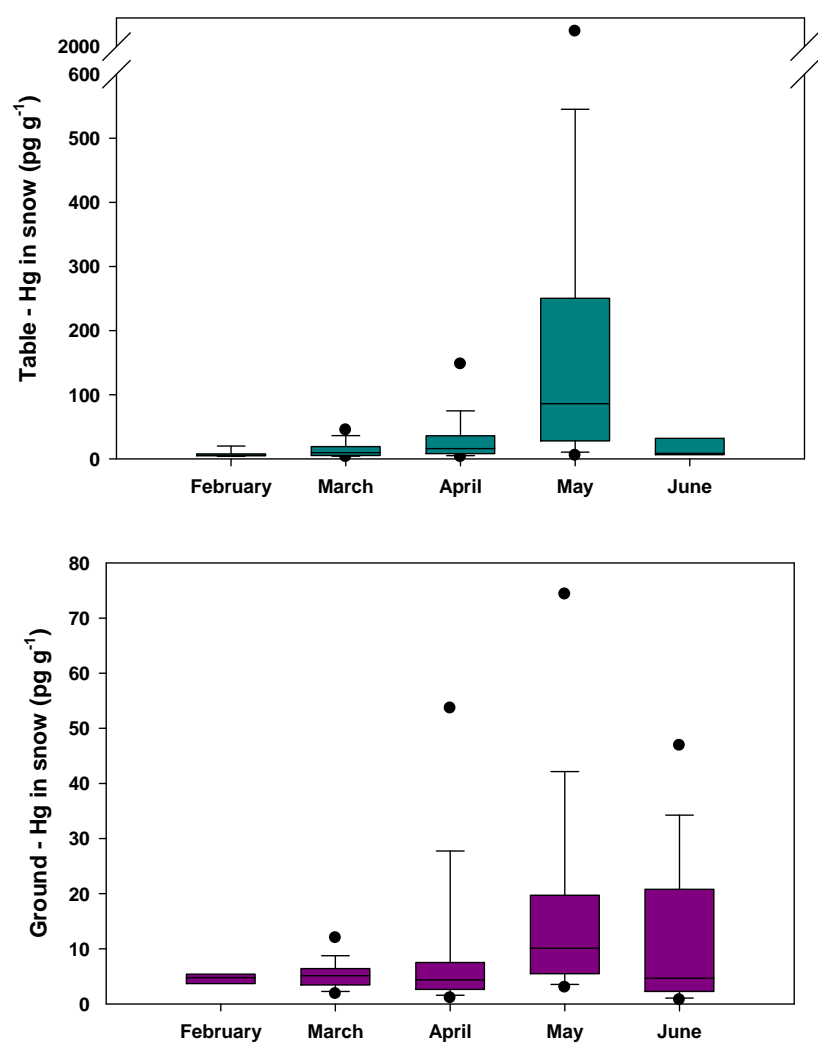

Fig. 7. Long-term snow sampling measurements at Alert from 1998 to 2011 sampled on an event basis. Samples are expressed as concentration of mercury $\left(\mathrm{pg} \mathrm{g}^{-1}\right)$ and were collected from a Teflon ${ }^{\circledR}$ covered table (top - blue) and from the top layer of the snow pack (bottom - purple). The centre line in the box represents the median value, the boundaries of the box represent the 25 th and 75 th percentiles, the whiskers represent the 10th and 90th percentile and the dots represent the 5 th and 95 th percentile.

more efficiently by snow than RGM (Amos et al., 2012), it appears that the highest levels of mercury in the snow are when $[\mathrm{RGM}]$ dominates the atmospheric mercury levels. RGM has a higher dry deposition velocity than PHg (Zhang et al., 2009) and can readily deposit onto the snow surfaces. Thus, when the atmospheric conditions favour RGM, higher levels of mercury in the snow should be expected. Overall, this data show that the highest deposition of mercury to the snow in the spring at Alert is during and after the transition of $[\mathrm{PHg}]$ to $[\mathrm{RGM}]$ in the atmosphere.

\section{Conclusions}

We investigate what can be learned from a study of the composition of the air and its impact on the snow as observed at Alert, Canada. Atmospheric speciated mercury measurements reveal strong seasonality as well as significant variability within the spring season. The $[\mathrm{PHg}]$ are found to be low in the summer, increasing towards the winter and peak-

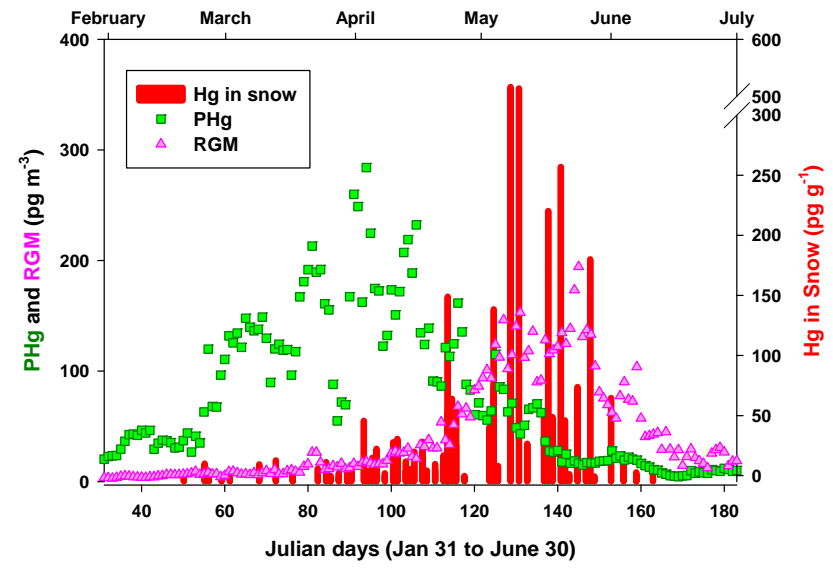

Fig. 8. Atmospheric mercury speciation concentration data $\mathrm{PHg}$ and RGM ( $\mathrm{pg} \mathrm{m}^{-3}$ ) and $\mathrm{Hg}$ concentration $\left(\mathrm{pg} \mathrm{g}^{-1}\right)$ from the snow (table) from February to June for all data from 2002 to 2011. The atmospheric data have been averaged per Julian day over all the years.

ing in March and April. [RGM] levels are lowest from August to February, peak in May and remain elevated until July. The most significant finding is the abrupt transition of high concentration levels of PHg to high concentration levels of RGM from April to May that is reproduced each spring over a 10 year period. Fourteen years of snow sampling data from Alert show that the concentrations of mercury in the snow increase as the spring season progresses, peak in May and decrease thereafter.

The results from this long-term data set show that temperature and particle availability impact the transition of $[\mathrm{PHg}]$ to $[\mathrm{RGM}]$ in the Arctic spring at Alert. The results show a higher fraction of $\mathrm{PHg}$ at low temperatures and we conclude that this is due to increased partitioning of RGM, produced through the AMDE chemistry, to the available particles. Prior to the transition, when $\mathrm{PHg}$ levels are very high, the median air temperature is $-24.8^{\circ} \mathrm{C}$ and after the transition, when RGM levels are very high, the median air temperature is $-5.8^{\circ} \mathrm{C}$. Further, the availability of high levels of aerosols during the springtime appears to be an important factor in the transition of high $[\mathrm{PHg}]$ to high $[\mathrm{RGM}]$ that is consistently reported during the Alert springtime period. From February to April, particles such as Arctic haze and sea salts provide increased surface area onto which RGM can partition. The strong decrease in the particle concentration in the air in May is concurrent with a sharp decline in $[\mathrm{PHg}]$. The subsequent elevated [RGM] in May and June is concurrent with a lack of particles in the air. More investigation is needed to determine the role of particle type on this transition.

Fourteen years of snow sampling at Alert show that the concentrations of mercury in the snow increase as the spring AMDE season progresses and peak in May. Ten years of data from the snow and atmospheric measurements are combined to show that during the transition from a high $[\mathrm{PHg}]$ to a high $[R G M]$ domain there is a concurrent increase in the 
concentration of mercury in the snow. It was concluded that when the atmospheric conditions favour high [RGM], higher levels of mercury in the snow are reported. Therefore, the conditions in the atmosphere directly impact when the highest amount of mercury will be deposited to the snow during the Arctic spring.

Acknowledgements. Over 14 years of data represents the work of many people and not only the authors. The authors wish to thank Environment Canada's Arctic coordinator Andrew Platt, the many operators and students working in the Neil Trivett GAW laboratory at Alert during this time for maintaining the instruments and collecting all the samples and P. Lee and J. Deary for excellent technical support over the years. Special thanks to C. Ferrari and C. Scherz whose preliminary work on this data put this ship on the right path, and to J. Narayan whose constant help with data is invaluable and to G. Skelton for the QC development and implementation. Thanks to S. Sharma for the nephelometer data and A. Platt for the meteorological data. The Air Quality Research Division and the Climate Research Division of Environment Canada and Aboriginal Affairs and Northern Development Canada, Northern Contaminants Program are acknowledged for their longterm commitment and financial support for this program. Finally, thanks to the Arctic Monitoring and Assessment Programme for their long-term interest and support of this research.

Edited by: A. Dastoor

\section{References}

Amos, H. M., Jacob, D. J., Holmes, C. D., Fisher, J. A., Wang, Q., Yantosca, R. M., Corbitt, E. S., Galarneau, E., Rutter, A. P., Gustin, M. S., Steffen, A., Schauer, J. J., Graydon, J. A., Louis, V. L. St., Talbot, R. W., Edgerton, E. S., Zhang, Y., and Sunderland, E. M.: Gas-particle partitioning of atmospheric $\mathrm{Hg}(\mathrm{II})$ and its effect on global mercury deposition, Atmos. Chem. Phys., 12, 591-603, doi:10.5194/acp-12-591-2012, 2012.

Anderson, T. L. and Ogren, J. A.: Determining aerosol radiative properties using the TSI 3563 integrating nephelometer, Aerosol Sci. Tech., 29, 57-69, doi:10.1080/02786829808965551, 1998.

Anderson, T. L., Covert, D. S., Wheeler, J. D., Harris, J. M., Perry, K. D., Trost, B. E., Jaffe, D. J., and Ogren, J. A.: Measured values and uncertainties at a coastal station in the Pacific Northwest, J. Geophys. Res., 104, 26793-26807, doi:10.1029/1999JD900172, 1999

Ariya, P., Dastoor, A., Amyot, M., Schroeder, W., Barrie, L., Anlauf, K., Raofie, F., Ryzhkov, A., Davignon, D., Lalonde, J., and Steffen, A.: The Arctic: A sink for mercury, Tellus B, 56, 397403, 2004.

Ariya, P., Skov, H., Grage, M. M.-L., and Goodsite, M. E.: Gaseous elemental mercury in the ambient atmosphere: review of the application of theoretical calculations and experimental studies for determination of reaction coefficients and mechanisms with halogens and other reactants, Adv. Quantum Chem., 55, 43-55, doi:10.1016/S0065-3276(07)00204-3, 2008.

Aspmo, K., Gauchard, P.-A., Steffen, A., Temme, C., Berg, T., Bahlmann, E., Banic, C., Dommergue, A., Ebinghaus, R., Ferrari, C., Pirrone, N., Sprovieri, F., and Wibetoe, G.: Measure- ments of atmospheric mercury species during an international study of mercury depletion events at Ny-Alesund, Svalbard, spring 2003. How reproducible are our present methods?, Atmos. Environ., 39, 7607-7619, 2005.

Barrie, L. A.: Arctic air pollution: An overview of current knowledge, Atmos. Environ., 20, 643-663, 1986.

Barrie, L. A., Olson, M. P., and Oikawa, K. K.: The flux of anthropogenic sulphur into the Arctic from mid-latitudes in 1979/80, Atmos. Environ., 23, 2505-2512, 1989.

Bottenheim, J. and Chan, E.: A trajectory study into the origin of spring time Arctic boundary layer ozone depletion, J. Geophys. Res., 111, D19301, doi:10.1029/2006JD007055, 2006.

Boutron, C. F., Vandal, G. M., Fitzgerald, W. F., and Ferrari, C. P.: A forty-year record of mercury in central Greenland snow, Geophys. Res. Lett., 25, 3315-3318, 1998.

Brooks, S. B., Saiz-Lopez, A., Skov, H., Lindberg, S. E., Plane, J. M. C., and Goodsite, M. E. G.: The mass balance of mercury in the springtime arctic environment, Geophys. Res. Lett., 33, L13812, doi:10.1029/2005GLO25525, 2006.

Carignan, J. and Sonke, J.: The effect of atmospheric mercury depletion events on the net deposition flux around Hudson Bay, Canada, Atmos. Environ., 44, 4372-4379, 2010.

Cobbett, F. D., Steffen, A., Lawson, G., and Van Heyst, B. J.: GEM fluxes and atmospheric mercury concentrations (GEM, RGM and $\mathrm{HgP}$ ) in the Canadian Arctic at Alert, Nunavut, Canada (February-June 2005), Atmos. Environ., 41, 6527-6543, 2007.

Cole, A. S. and Steffen, A.: Trends in long-term gaseous mercury observations in the Arctic and effects of temperature and other atmospheric conditions, Atmos. Chem. Phys., 10, 4661-4672, doi:10.5194/acp-10-4661-2010, 2010.

Cole, A. S., Steffen, A., Pfaffhuber, K. A., Berg, T., Pilote, M., Poissant, L., Tordon, R., and Hung, H.: Ten-year trends of atmospheric mercury in the high Arctic compared to Canadian subArctic and mid-latitude sites, Atmos. Chem. Phys., 13, 15351545, doi:10.5194/acp-13-1535-2013, 2013.

Constant, P., Poissant, L., Villemur, R., and Lean, D.: Fate of mercury and methylmercury within the snow cover at Whapmagoostui-Kuujjuarapik (Québec, Canada), J. Geophys. Res.-Atmos., 112, D08309, doi:10.1029/2006JD007961, 2007.

Dastoor, A., Davignon, D., Theys, N., van Roozendael, M., Steffen, A., and Ariya, P.: Modeling dynamic exchange of gaseous elemental mercury at polar sunrise, Environ. Sci. Technol., 42, 5183-5188, 2008.

Dommergue, A., Ferrari, C. P., Poissant, L., Gauchard, P.-A., and Boutron, C. F.: Chemical and photochemical processes at the origin of the diurnal cycle of gaseous mercury within the snow-pack at Kuujjuarapik, Québec, Environ. Sci. Technol., 37, 3289-3297, 2003a.

Dommergue, A., Ferrari, C. P., Gauchard, P.-A., Boutron, C. F., Poissant, L., Pilote, M., Jitaru, P., and Adams, F.: The fate of mercury species in a sub-arctic snow-pack during snowmelt, Geophys. Res. Lett., 30, 23-21, doi:10.1029/2003GL017308, 2003b.

Dommergue, A., Ferrari, C. P., Amyot, M., Brooks, S., Sprovieri, F., and Steffen, A.: Spatial Coverage and Temporal Trends of Atmospheric Mercury Measurements in Polar Regions, in: Mercury Fate and Transport in the Global Atmopshere. Emissions, Measurements and Models, edited by: Pirrone, N. and Mason, R. P., Soringer, New York, 293-321, 2009. 
Douglas, T. A. and Sturm, M.: Arctic haze, mercury and the chemical composition of snow across western Alaska, Atmos. Environ., 38, 805-820, 2004.

Douglas, T. A., Sturm, M., Simpson, W., Brooks, S., Lindberg, S., and Perovich: Elevated mercury measured in snow and frost flowers near arctic sea ice leads, Geophys. Res. Lett., 32, 1-4, 2005.

Douglas, T., Sturm, M., Simpson, W., Blum, J., Alvarez-Aviles, L., Keeler, G., Perovich, D., Biswas, A., and Johnson, K.: The influence of snow and ice crystal formation and accumulation on mercury deposition to the Arctic, Environ. Sci. Technol., 42, 15421551, 2008.

Douglas, T. A., Loseto, L. L., MacDonald, R., Outridge, P. M., Dommergue, A., Poulain, A. J., Amyot, J. D., Barkay, T., Berg, T., Chetelat, J., Constant, P., Evans, M. S., Ferrari, C., Gantner, N., Johnson, M. S., Kirk, J. L., Kroer, N., Larose, C., Lean, D., Nielsen, T. G., Poissant, L., Rognerud, S., Skov, H., Sorensen, S., Wang, F., Wilson, S., and Zdanowicz, C. M.: The fate of mercury in Arctic terrestrial and aquatic ecosystems, a review, Environ. Chem., 9, 321-355, doi:10.1071/EN11140, 2012.

Durnford, D., Dastoor, A., Figueras-Nieto, D., and Ryjkov, A.: Long range transport of mercury to the Arctic and across Canada, Atmos. Chem. Phys., 10, 6063-6086, doi:10.5194/acp-10-60632010, 2010.

Durnford, D. and Dastoor, A.: The behavior of mercury in the cryosphere: A review of what we know from observations, J. Geophys. Res.-Atmos., 116, D06305, doi:10.1029/2010JD014809, 2011.

Durnford, D., Dastoor, A., Ryzhkov, A., Poissant, L., Pilote, M., and Figueras-Nieto, D.: How relevant is the deposition of mercury onto snowpacks? - Part 2: A modeling study, Atmos. Chem. Phys., 12, 9251-9274, doi:10.5194/acp-12-9251-2012, 2012.

Ferrari, C. P., Dommergue, A., Boutron, C. F., Skov, H., Goodsite, M., and Jensen, B.: Nighttime production of elemental gaseous mercury in interstitial air of snow at Station Nord, Greenland, Atmos. Environ., 38, 2727-2735, 2004a.

Ferrari, C. P., Dommergue, A., and Boutron, C. F.: Profiles of mercury in the snow pack at Station Nord, Greenland shortly after polar sunrise, Geophys. Res. Lett., 31, L03401, doi:10.1029/2003GLO18961, 2004b.

Ferrari, C. P., Gauchard, P. A., Dommergue, A., Magand, O., Nagorski, S., Boutron, C. F., Temme, C., Bahlmann, E., Ebinghaus, R., Steffen, A., Banic, C., Aspmo, K., Berg, T., Planchon, F., and Barbante, C.: Snow to air exchange of mercury in an Arctic seasonal snow pack in Ny-Alesund, Svalbard, Atmos. Environ., 39, 7633-7645, 2005.

Fitzgerald, W. F., Engstrom, D. R., Lamborg, C. H., Tseng, C.-M., and Balcom, P. H.: Modern and historic atmospheric mercury fluxes in northern Alaska: global sources and Arctic depletion, Environ. Sci. Technol., 39, 557-568, 2005.

Gong, S. L., Barrie, L. A., Prospero, J. M., Savoie, D. L., Ayers, G. P., Blanchet, J.-P., and Spacek, L.: Modeling sea-salt aerosols in the atmosphere 2. Atmospheric concentrations and fluxes, J. Geophys. Res., 102, 3819-3830, 1997.

Gustin, M. and Jaffe, D.: Reducing uncertainty in measurement and understanding of mercury in the atmosphere, Environ. Sci. Technol., 44, 2222-2227, 2010.

Holmes, C. D., Jacob, D. J., Mason, R. P., and Jaffe, D. A.: Sources and deposition of reactivegaseous mercury in the marine atmosphere, Atmos. Environ., 43, 2278-2285, doi:10.1016/j.atmosenv.2009.01.051, 2009.

Kirk, J. L., St. Louis, V. L., and Sharp, M. J.: Rapid reduction and reemission of mercury deposited into snow packs during atmospheric mercury depletion events at Churchill, Manitoba, Canada, Environ. Sci. Technol., 40, 7590-7596, 2006.

Lahoutifard, N., Sparling, M., and Lean, D.: Total and methyl mercury patterns in Arctic snow during springtime at Resolute, Nunavut, Canada, Atmos. Environ., 39, 7597-7606, 2005.

Lalonde, J. D., Poulain, A. J., and Amyot, M.: The role of mercury redox reactions in snow on snow-to-air mercury transfer, Environ. Sci. Technol., 36, 174-178, 2002.

Landis, M., Stevens, R. K., Schaedlich, F., and Prestbo, E. M.: Development and characterization of an annular denuder methodology for the measurement of divalent inorganic reactive gaseous mercury in ambient air, Environ. Sci. Technol., 36, 3000-3009, 2002.

Leaitch, W. R., Sharma, S., Huang, L., Toom-Sauntry, D., Chivulescu, A., MacDonald, A. M., von Salzen, K., Pierce, J. R., Bertram, A. K., Schroder, J. C., Shanz, N. C., Chang, R. Y.W., and Norman, A.-L.: Dimethyl sulfide control of the clean summertime arctic aerosol and cloud, Elementa: Science of the Anthropocene, in press, 2014.

Lin, C. J.: Scientific uncertainties in atmospheric mercury models I: Model science evaluation, Atmos. Environ., 40, 2911-2928, 2006.

Lindberg, S. E., Brooks, S., Lin, C.-J., Scott, K. J., Landis, M. S., Stevens, R. K., Goodsite, M., and Richter, A.: Dynamic oxidation of gaseous mercury in the Arctic troposphere at polar sunrise, Environ. Sci. Technol., 36, 1245-1256, 2002.

Lindberg, S., Bullock, R., Ebinghaus, R., Engstrom, D. R., Feng, X., Fitzgerald, W. F., Pirrone, N., Prestbo, E., and Seigneur, C.: A synthesis of progress and uncertainties in attributing the sources of mercury in deposition, Ambio, 36, 19-32, 2007.

Lindberg, S. E., Brooks, S. B., Lin, C. J., Scott, K., Meyers, T., Chambers, L., Landis, M., and Stevens, R. K.: Formation of reactive gaseous mercury in the Arctic: evidence of oxidation of $\mathrm{Hg} 0$ to gas-phase $\mathrm{Hg}$-II compounds after arctic sunrise, Water Air Soil Poll., 1, 295-302, 2001.

Lu, J. Y., Schroeder, W. H., Barrie, L. A., Steffen, A., Welch, H. E., Martin, K., Lockhart, L., Hunt, R. V., Boila, G., and Richter, A.: Magnification of atmospheric mercury deposition to polar regions in springtime: the link to tropospheric ozone depletion chemistry, Geophys. Res. Lett., 28, 3219-3222, 2001.

Malcolm, E. G., Ford, A. C., Redding, T. A., Richardson, M. C., Strain, B., and Tetzner, S. W.: Experimental investigation of the scavenging of gaseous mercury by sea salt aerosol, J. Atmos. Chem., 63, 221-234, doi:10.1007/s10874-010-9165-y, 2010.

Moore, C., Steffen, A., Obrist, D., Staebler, R., and Nghiem, S.: Influence of Sea Ice Dynamics on Atmospheric Mercury and Ozone Concentrations and Fluxes during the BROMEX Campaign American Geophysical Union Fall Meeting, San Francisco, CA, 2012.

Obrist, D., Tas, E., Peleg, M., Matveev, V., Fain, X., Asaf, D., and Luria, M.: Bromine-induced oxidation of mercury in the midlatitude atmosphere, Nat. Geosci., 4, 22-26, 2011.

Outridge, P. M., Macdonald, R. W., Wang, F., Stern, G. A., and Dastoor, A. P.: A mass balance inventory of mercury in the Arctic Ocean, Environ. Chem., 5, 89-111, doi:10.1071/en08002, 2008. 
Peterson, C., Gustin, M., and Lyman, S.: Atmospheric mercury concentrations and speciated measured from 2004 to 2007 in Reno, Nevada, USA, Atmos. Environ., 43, 4646-4654, doi:10.1016/j.atmosenv.2009.04.053, 2009.

Poissant, L., Zhang, H. H., Can $\tilde{A}_{i}$ rio, J., and Constant, P.: Critical review of mercury fates and contamination in the arctic tundra ecosystem, Sci. Total Environ., 400, 173-211, 2008.

Poulain, A. J., Garcia, E., Amyot, M., Campbell, P. G. C., and Ariya, P.: Mercury distribution, partitioning and speciation in coastla vs. inland high arctic snow, Geochim. Cosmochim. Ac., 71, 34193431, 2007.

Quinn, P. K., Shaw, G. E., Andrews, E., Dutton, E. G., RuhohAirola, T., and Gong, S.: Arctic Haze: current trends and knowledge gaps, Tellus B, 59, 99-111, doi:10.1111/j.16000889.2006.00238.x, 2007.

Rutter, A. P. and Schauer, J. J.: The impact of aerosol composition on the particle to gas partitioning of reactive mercury, Environ. Sci. Technol., 41, 3934-3939, 2007a.

Rutter, A. P. and Schauer, J. J.: The effect of temperature on the gas-particle partitioning of reactive mercury in atmospheric aerosols, Atmos. Environ., 41, 8647-8657, doi:10.1016/j.atmosenv.2007.07.04, 2007b.

Schroeder, W. H. and Munthe, J.: Atmospheric mercury - An overview, Atmos. Environ., 32, 809-822, 1998.

Schroeder, W. H., Anlauf, K. G., Barrie, L. A., Lu, J. Y., Steffen, A., Schneeberger, D. R., and Berg, T.: Arctic springtime depletion of mercury, Nature, 394, 331-332, 1998.

Sharma, S., Lavoue, D., Cachier, H., Barrie, L. A., and Gong, S. L.: Long-term trends of the black carbon concentrations in the Canadian Arctic, J. Geophys. Res., 109, D15203, doi:10.1029/2003JD004331, 2004.

Sharma, S., Ishizawa, M., Chan, D., Lavoue, D., Andrews, E., Eleftheriadis, K., and Maksyutov, S.: 16-year simulation of Acrtic black carboL transport, source, contribution and sensitivity analysis on deposition, J. Geophys. Res., 118, 1-22, doi:10.1029/2012JD017774, 2013.

Sheridan, P. J., Jefferson, A., and Ogren, J. A.: Spatial variability of submicrometer aerosol radiative properties over the Indian Ocean during INDOEX, J. Geophys. Res., 107, 8011, doi:10.1029/2000JD000166, 2002

Sheu, G.-R. and Mason, R. P.: An examination of the oxidation of elemental mercury in the presence of halide surfaces, J. Atmos. Chem., 48, 107-130, 2004.

Simpson, W. R., von Glasow, R., Riedel, K., Anderson, P., Ariya, P., Bottenheim, J., Burrows, J., Carpenter, L. J., Frieß, U., Goodsite, M. E., Heard, D., Hutterli, M., Jacobi, H.-W., Kaleschke, L., Neff, B., Plane, J., Platt, U., Richter, A., Roscoe, H., Sander, R., Shepson, P., Sodeau, J., Steffen, A., Wagner, T., and Wolff, E.: Halogens and their role in polar boundary-layer ozone depletion, Atmos. Chem. Phys., 7, 4375-4418, doi:10.5194/acp-74375-2007, 2007.
Sirois, A. and Barrie, L. A.: Arctic lower troposheric aerosol trends and composition at Alert, Canada: 1980-1995, J. Geophys. Res., 104, 11599-11618, 1999.

Skov, H., Goodsite, M. E., Lindberg, S. E., Meyers, T. P., Landis, M., Larsen, M. R. B., and McConville, G.: The fluxes of Reactive Gaseous mercury measured with a newly developed method using relaxed eddy accumulation, Atmos. Environ., 40, 5452-5463, 2006.

Sprovieri, F., Pirrone, N., Landis, M., and Stevens, R. K.: Oxidation of gaseous elemental mercury to gaseous divalent mercury during 2003 polar sunrise at Ny-Alesund, Environ. Sci. Technol., 39, 9156-9165, 2005.

St. Louis, V. L., Sharp, M. J., Steffen, A., May, A., Barker, J., Kirk, J. L., Kelly, D. J. A., Arnott, S. E., Keatley, B., and Smol, J. P.: Some Sources and Sinks of Monomethyl and Inorganic Mercury on Ellesmere Island in the Canadian High Arctic, Environ. Sci. Technol., 39, 2686-2701, 2005.

Steen, A. O., Berg, T., Dastoor, A. P., Durnford, D. A., Engelsen, O., Hole, L. R., and Pfaffhuber, K. A.: Natural and anthropogenic atmospheric mercury in the European Arctic: a fractionation study, Atmos. Chem. Phys., 11, 6273-6284, doi:10.5194/acp-11-62732011, 2011.

Steffen, A., Schroeder, W. H., Macdonald, R., Poissant, L., and Konoplev, A.: Mercury in the Arctic atmosphere: an analysis of eight years of measurements of GEM at Alert (Canada) and a comparison with observations at Amderma (Russia) and Kuujjuarapik (Canada), Sci. Total Environ., 342, 185-198, 2005.

Steffen, A., Douglas, T., Amyot, M., Ariya, P., Aspmo, K., Berg, T., Bottenheim, J., Brooks, S., Cobbett, F., Dastoor, A., Dommergue, A., Ebinghaus, R., Ferrari, C., Gardfeldt, K., Goodsite, M. E., Lean, D., Poulain, A. J., Scherz, C., Skov, H., Sommar, J., and Temme, C.: A synthesis of atmospheric mercury depletion event chemistry in the atmosphere and snow, Atmos. Chem. Phys., 8 , 1445-1482, doi:10.5194/acp-8-1445-2008, 2008.

Steffen, A., Bottenheim, J., Cole, A., Douglas, T. A., Ebinghaus, R., Friess, U., Netcheva, S., Nghiem, S., Sihler, H., and Staebler, R.: Atmospheric mercury over sea ice during the OASIS-2009 campaign, Atmos. Chem. Phys., 13, 7007-7021, doi:10.5194/acp-137007-2013, 2013

Zhang, L., Wright, L. P., and Blanchard, P.: A review of current knowledge concerning dry deposition of atmospheric mercury, Atmos. Environ., 43, 5853-5864, 2009. 